\title{
WRF の計算特性に関する幾つかの検討
}

\author{
Study of some characteristics of WRF calculation
}

\author{
鈴山勝之 $^{1} \cdot$ 柴木秀之 ${ }^{2} \cdot$ 尾形竹彦 $^{3}$ \\ Katsuyuki SUZUYAMA, Hidenori SHIBAKI and Takehiko OGATA
}

\begin{abstract}
One of the important procedures for Disaster Prevention Plan is to determine accurately the window condition of an approaching typhoon. By using the Meteorological Model, it enables the aforementioned situation to be specified. The purpose of this study is for the method application to the Disaster Prevention Plan. The effect examined is due to the difference of several computational condition by Typhoon 0416 and 0418 . This reveals the property model of WRF. In addition to that, we enumerated the problem issued from the model utilization in order to make the application easy. According to the study, it is proved that Four Dimensional Data Assimilation greatly influences reproducibility of typhoon path. The magnitudes of central pressure and wind velocity speed are susceptible to the parameters of microphysics scheme etc.
\end{abstract}

\section{1. はじめに}

高潮推算や波浪推算の高精度化を図る方法の一つとし て，外力となる風速や気圧などの気象場を時空間的に精 度よく推定することが求められる。

WRF（Weather Research and Forecast）は米国大気研究 センター（NCAR：National Center for Atmospheric Research）を中心に開発が進められているオープンソー スの局地気象モデルであり, 現在の最新版はWRF3.3で ある. 近年, 海岸工学の分野でも気象場の計算に利用さ れて抢り，安田ら (2008，2009）や中野ら（2010）によ ってその有用性が示されている. しかし, 現段階では大 学や一部の研究機関の利用に限られ, 必ずしも一般的な 技術者が広く実務に適用できるまでには至っていない。 これは, WRFがコミュニティーモデルでありながらも， パラメー夕等の設定の難解さと計算特性の把握の困難さ を有していることが大きな障害となっているからであろ う. そこで本研究では, WRFの導入にあたり発生が予測 される問題点と対応を示すとともに，モデルの特性を明 らかにすることで，今後の実務への適用に資することを 目的とする.

\section{2. 気象モデルの概要}

WRFは既に開発が終了したMM5 の次世代のモデルで ある. 高次の差分スキームを有する圧縮性の非静力学モ デルで, 最新の物理モデル（放射, 乱流, 雲物理, 地表 面等）と，より進んだデー夕同化システムが利用でき, 数メートルから数千キロメートルといった幅広い領域設

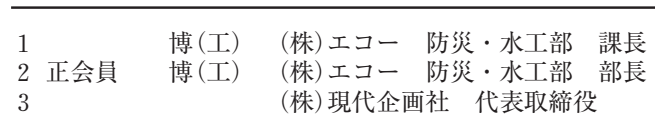

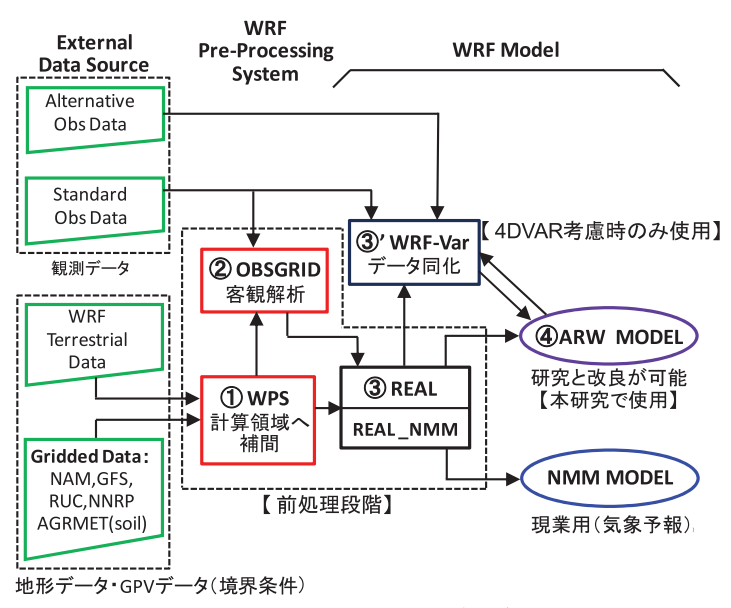

図-1 WRFモデルの概要

定に対応可能であることも特徵の一つである. WRFを導 入する際は, 計算に必要な機能がパッケージ化されたソ ースコードをダウンロードした後, 境界条件となるデー タセットを準備する. 図-1に にRFの機能の概要図を示す. WRFの処理は(1)〜 (4)の順番で行われる.WRFには研究 を主目的とするARW MODELと現業（気象予報）などへ の利用を推奨するNMM MODELの2 種類がある. 本研究 では, 高潮推算や波浪推算モデルとの相互利用が容易な 格子座標が用いられ，4次元変分法（4DVAR）による同 化（WRF-Var）の整備が進んでいることなどから, 今後 の発展性が期待できるARW MODELを選択した。

本研究の検討に用いたバージョンはWRF3.2.1である.

\section{3. モデルの導入と特性}

(1) 地形データ

地形データの作成はWPSで行う. WPSには世界測地 
WGS-84系を基準座標とする全球標高と, 10 分, 5分, 2 分， 30 秒の 4 種類の区画毎に土地利用データが用意され ている.これらのデータと geogridプログラムにより, 設 定した計算領域に対応した地形データが作成される。計 算領域を設定する場合, 固定座標系と移動座標系を選択 できるが，本研究では主に台風の計算特性について検討 を行うため移動座標系の領域 (Moving Nest) を選択した. 移動座標系の場合, 第 1 領域（Domain1）の地形情報を 基準として第2 領域（Domain2）以降の地形を補間によ り求めるため, Domain2 以降は格子間隔が小さくても地 形近似はさほど改善しない。ただし，移動座標系の特性 は台風近傍の計算精度を確保しつつ計算資源が節約でき ることにあり，各種計算条件に対する感度分析のための 多数の計算を行う場合には有効な領域設定法となる。ま た，時に数十ケースの計算を行う必要が生じる実務では 便利な機能と言える。これに対し固定座標系は, 各計算 領域の格子間隔に応じた地形が作成できるため, 高精度 な波浪や高潮の計算を行う場合など, 詳細な地形条件下 の気象場を必要とするときに選択される.

本研究ではWRFに付属したサンプル領域の構成を参考 に, 日本周辺海域を $12 \mathrm{~km}$ 格子で近似し, 台風周辺を $4 \mathrm{~km}$ 格子と $1.33 \mathrm{~km}$ 格子の移動座標系として設定した. 図-2に 移動座標系の領域の設定例を示す.

\section{（2）初期値・境界値データ}

初期值・境界值に用いる気象データの作成は図-1に示 したWPS, OBSGRID, REALで行う。まずWPSでは metgridプログラムを用い, 予め入手した GPV（Grid Point Value）デー夕を設定した計算領域へ補間する。本 研究で用いた GPVデー夕は, 格子間隔が $1^{\circ}$ と粗いデー タセット ds083.2である。このデータセットでは台風の微 細な構造（中心気圧や位置等）をとらえることはできな

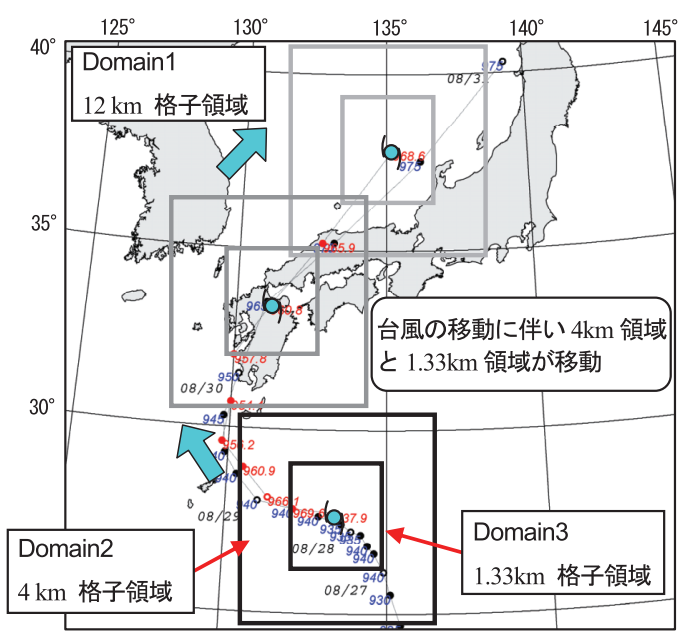

図-2 移動座標系の計算領域設定例
いが, 気象庁から公表されている水平格子間隔 $10 \mathrm{~km}$ の メソ客観解析デー夕（以下ではMSM と記す）と異なり， 土壤（Soil）デー夕や海面水温（SST）データなどWRF の計算に必要な全データが含まれる。次にOBSGRIDで は，WPSで作成した補間デー夕に対して観測デー夕（任 意座標地点の風データ及びボーガスデータなど）による 客観解析を行う。本研究では観測データセットとして ds461.0（地上, 船舶など）とds351.0（高層, 衛星など） を用いた。ds083.2を用いる場合，WPS とOBSGRIDで作 成されるデー夕に大きな差は見られない，その後REAL において，客観解析された補間デー夕を鉛直方向の気圧 準拠座標 $(\eta$ 座標 $)$ へ変換する.このとき 4 次元同化手 法の一つである Nudgingに用いる入力デー夕も作成さ れる。

台風を対象に地形デー夕や初期值・境界值デー夕を作 成する場合, 助走期間の考慮が重要であり, 特に $\mathrm{ds} 083.2$ のような解像度の粗いGPVデータを用いる場合は必須と なる，本研究では幾つかの試計算結果とベストトラック の中心気圧の比較から, 台風0416号と0418号が十分に 発達した状態で対象海域に到達するための助走期間とし て約 48 時間以上が必要との結果を得た。しかし，例えば MSM どの高解像度の GPVデー夕を使用する場合は， 初期值・境界值デー夕自体が台風の構造を十分に再現し ているため, 助走期間はほとんど必要なく, 数時間程度 あれば十分と考えられる.

\section{（3）モデルの特性}

\section{a) 格子間隔と移動座標系領域の影響}

図-3では，格子間隔と計算領域（Domain2）の広さが 計算結果に及ぼす影響を確認する，格子間隔の影響の確 認は，最小格子領域である Domain3 まで用いた 3 領域の 計算結果（D3N）とDomain3を除外した2領域の計算結 果（D2N）の経路と中心気圧の比較より行う。計算では Nudgingによる4次元同化を考慮している. ベストトラッ クとの近似度を見ると， D2Nは中心気圧が若干大きくな るものの, 経路については北緯 $28^{\circ}$ 以北から九州上陸後 にかけて近似度はよい. D3Nは中心気圧の近似度はよい ものの経路のずれが大きい. 本研究では台風経路の近似 度がよい計算条件を採用し, 以降の検討ではDomain3を 除外した 2 領域のみの計算を行うこととした.

次に台風の移動に追従するDomain2の大きさを変更 し，計算領域の広さの影響を確認する，D2Nの Domain2 の大きさは対象台風全体を覆うように $720 \mathrm{~km} \times 720 \mathrm{~km}$ 設定した。これに対し, Domain2の大きさを $600 \mathrm{~km} \times$ $600 \mathrm{~km}$ と設定した計算（D2N600）を行いベストトラック と比較したところ, 中心気圧の近似度はD $2 \mathrm{~N}$ と同程度で あったが, 経路のずれが大きくなった。これより， Domain2の広さは台風縁辺を含む $700 \sim 1000 \mathrm{~km}$ が必要で 


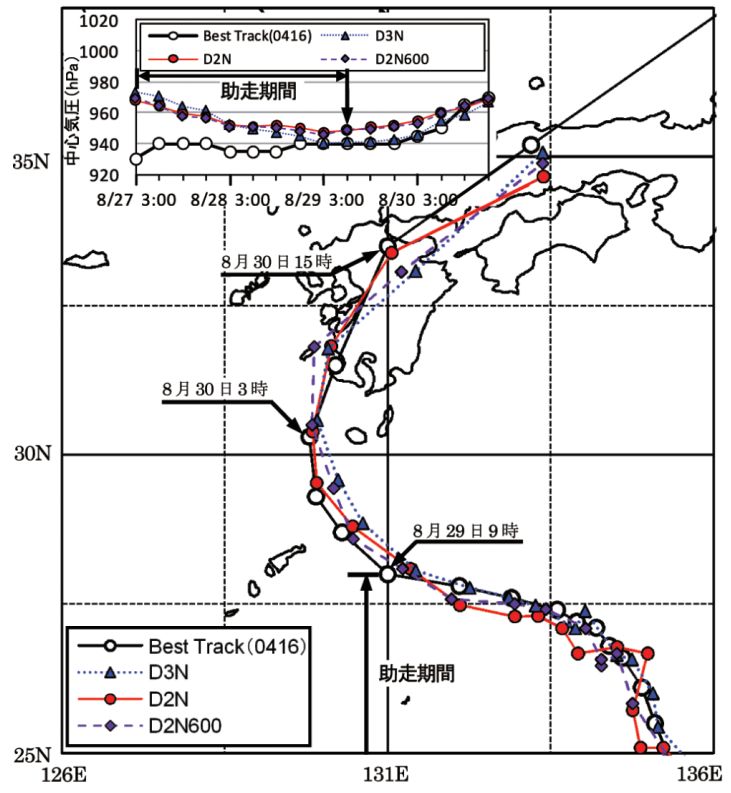

図-3 格子間隔と計算領域が及ぼす影響

あり, Domain1の領域はDomain2の広さ, 助走期間, corral_distなどを考慮しつつ設定することが重要である. また, 台風 0418 号についても同様な傾向を示すことを確 認した。

\section{b) Nudgingによる4 次元同化の影響}

WRFで利用できる代表的なデータ同化システムは Nudging と4DVARである.4DVARは現在の同化手法の 中で最も高度な手法の一つであり，実務においてはその 適用に極めて熟練を要する。そこで本研究ではNudging による4次元同化をDomain1に適用し，その影響を確認 する。図-4にNudging 考慮なし（D2）とあり（D2N）の 経路と中心気圧の比較を示す. Nudgingを考慮すると経 路の精度は向上するが, 中心気圧は若干大きくなる. 中 野ら（2010）は, Nudgingのスムージング効果によって 台風強度が過小評価される傾向を指摘しているが，ここ ではこの効果が出たものと考えられる.

また，Nudgingを適用するDomain1の範囲を東西方向 へ約 $2,000 \mathrm{~km}$, 南北方向へ $1,500 \mathrm{~km}$ 拡張した計算を行うこ とで, Domain1の計算領域の広さがNudgingに与える影 響を確認した. Domain1を拡張してNudging 考慮なしの 場合（D21）はベストトラックからの経路は大きくずれ る.これは計算領域を拡張したことで側面境界の影響が 薄れたことが原因と考えられる。ただし, Nudgingを行っ た場合（D21N）はDomain1の広さに関わらず計算精度は ほぼ同等になることが確認できる. 台風0418号に対して も同様の結果が得られたが, Domain1の拡張の影響は台 風0416号ほど大きくなく, Nudging 考慮なしの場合でも ベストトラックからの経路のずれは最大 $2^{\circ}$ 程度であった.

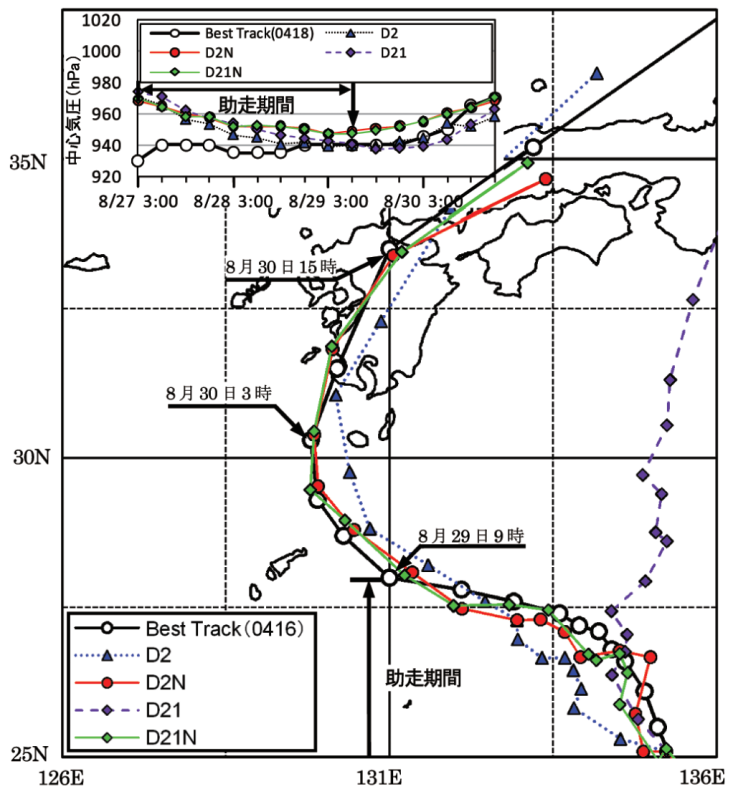

図-4 Nudgingによる4次元同化が及ぼす影響

表-1 計算ケース

\begin{tabular}{c|c|c|c|c|c}
\hline ケース & 層数 & omlcall & mp_physics & bogus & Nudging \\
\hline D2N & 27 & $\times$ & WSM3 & $\times$ & $\bigcirc$ \\
\hline D2N35 & 35 & $\times$ & WSM3 & $\times$ & $\bigcirc$ \\
\hline D2Nom1 & 27 & $\bigcirc$ & WSM3 & $\times$ & $\bigcirc$ \\
\hline D2Nom18 & 27 & $\bigcirc$ & Thompson & $\times$ & $\bigcirc$ \\
\hline D2Nbogus & 27 & $\bigcirc$ & WSM3 & $\bigcirc$ & $\bigcirc$ \\
\hline
\end{tabular}

ここではNudgingによる4次元同化が, 台風経路の推 定精度を劇的に向上させることを再確認した。ただし， 中心気圧に対する推定精度は低下する傾向にある.

\section{c）その他の計算条件の影響}

層数や物理モデルの違い, 台風ボーガスの有無が計算 結果に及ぼす影響を確認する。表-1に計算ケースを示す. 層数の影響は, 地表から $100 \mathrm{hPa}$ までを 27 層と 35 層に設 定し確認した。この時の最下層の条件は, $\eta=0.993$ で層 厚は約 $60 \mathrm{~m}$ となる. 物理モデルの影響は, 海洋混合層モ デル（1D Ocean Mixed-Layer Model：omlcall）の有無と, 微物理スキーム（Microphysics schemes：mp_physics）の 違いにより確認した.

図-5は，台風 0416 号と 0418 号に対する各計算ケースの 経路と中心気圧の比較である。表-2 は各計算ケースの結 果とベストトラックの近似度を評価するため, 助走期間 を除く評価期間内における経路, 中心気圧, 最大風速の 誤差を確認したものである. 期間内平均 (mean) と標準 偏差（sd）は6時間毎の台風位置, 中心気圧, 最大風速 に対してベストトラックからの差を求め, これを用いて 算出した. 台風 0416 号の評価期間は 8 月 29 日9時〜 30 日 
21 時（データ個数 7 個）, 台風 0418 号の評価期間は9 月 6 日9時〜 7日 15 時（デー夕個数6個）である.ただし，本 研究では計算条件の違いが結果に及ぼす影響を相対的に 比較するため，表による評価についても，值のオーダー の違いを確認する程度にとどめる。

全体的な傾向として，Nudgingの考慮により，計算条 件の違いが経路に及ぼす影響は小さくなるが，物理モデ ルの違いが中心気圧や最大風速へ及ぼす影響は大きい. 以下では，台風0416号に対する結果について述べる.

本研究の $\eta$ 座標の設定条件では層数の違い（D2N35） が経路, 中心気圧, 最大風速に及ぼす影響は小さい.

海洋混合層モデルの有無（D2Noml）は，経路と中心 気圧への影響は小さいが最大風速への影響は大きい。こ のモデルはハリケーンの計算で中心気圧の過度な発達を 抑制するために作成されたが，WRF付属のサンプル設定 ファイルでは利用しない形で提供されている.
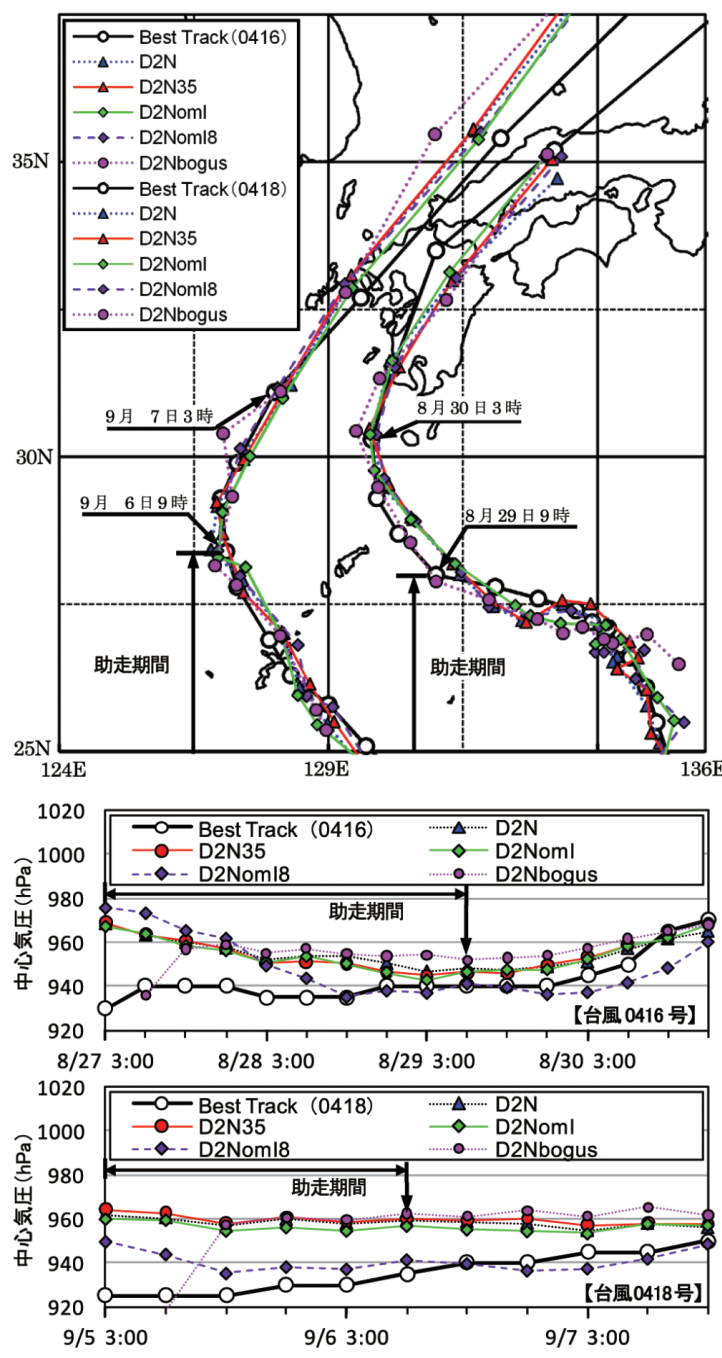

図-5 各種計算条件が及ぼす影響
微物理スキームの違い（D2Nom18）が経路に及ぼす影 響は小さいが，中心気圧と最大風速に及ぼす影響は大き い. User's Guideではハリケーン及び格子間隔 $1 \sim 4 \mathrm{~km}$ の 場合，mp_physicsに「Thompson 2009」のモデルを使用 することが推奨されている。計算された中心気圧に対し てベストトラックとの近似度を見ると, 海域での近似度 はよく，陸域通過時に過大評価となる傾向が見られる. この結果から明らかなように，他の全計算ケースの中心 気圧がNudgingの影響によりベストトラックを過小評価 しているにも関わらず，このケースの中心気圧のみが過 大評価となる，すなわち，微物理スキームの選択によっ てはNudgingを考慮した計算であっても中心気圧の過小 評価は起きない場合があることがわかった。

台風ボーガスの投入（D2Nbogus）が中心気圧へ及ぼす 影響は小さく，経路と最大風速への影響が確認できる. 本研究では岡垣ら（2010）の台風ボーガス投入方法を参 考に，6時間毎の観測データとして，台風中心から半径 $200 \mathrm{~km}$ の同心円上に 4 点のボーガスデータを投入した. 投入するボーガスデータとして，ベストトラックから中 心位置と中心気圧を, 半径 $200 \mathrm{~km}$ の同心円上には MSM の情報をそのまま利用した。しかしこの方法では台風内 の気圧場に四角形の歪みが発生したため,さらに4点を 追加し, 最終的に 8 点のボーガスデータを半径 $200 \mathrm{~km}$ の 同心円上に投入した．計算開始時の中心気圧は $940 \mathrm{hPa}$ 程 度になったものの 15 分後には $960 \mathrm{hPa}$ 程度に減衰したこ とから，ボーガス投入点の不足による客観解析に問題が あると推察される。したがって，本研究で作成した台風 ボーガスは不十分なものであり，これが台風の精度向上 に繋がらなかった原因の一つと考えられる。

さらに, 台風0418号の計算結果について見ると, 各計 算条件に対する経路と中心気圧の傾向は台風0416号と異 なることがわかる。これは，台風の違いによって最適な 物理モデルのパラメータも異なることを示唆している. ただし，本研究の検討だけでは設定すべき多くのパラメ

表-2 ベストトラックとの近似度の評価

\begin{tabular}{c|c|c|c|r|r|r|r}
\hline Typhoon & Case & $\begin{array}{c}\text { mean } \\
(\mathrm{km})\end{array}$ & $\begin{array}{c}\mathrm{sd} \\
(\mathrm{km})\end{array}$ & $\begin{array}{c}\text { mean } \\
(\mathrm{hPa})\end{array}$ & $\begin{array}{c}\mathrm{sd} \\
(\mathrm{hPa})\end{array}$ & $\begin{array}{c}\text { mean } \\
(\mathrm{m} / \mathrm{s})\end{array}$ & $\begin{array}{c}\mathrm{sd} \\
(\mathrm{m} / \mathrm{s})\end{array}$ \\
\hline \multirow{4}{*}{0416} & D2N & 35 & 39 & 4 & 7 & 1 & 3 \\
\cline { 2 - 8 } & D2N35 & 31 & 35 & 5 & 7 & 2 & 3 \\
\cline { 2 - 8 } & D2Noml & 31 & 35 & 4 & 6 & 5 & 5 \\
\cline { 2 - 8 } & D2Nom18 & 31 & 37 & -15 & 15 & 15 & 15 \\
\cline { 2 - 8 } & D2Nbogus & 33 & 42 & 9 & 11 & 5 & 5 \\
\hline \multirow{4}{*}{0418} & D2N & 32 & 33 & 15 & 16 & -4 & 5 \\
\cline { 2 - 8 } & D2N35 & 28 & 32 & 16 & 17 & -3 & 5 \\
\cline { 2 - 8 } & D2Noml & 25 & 26 & 13 & 14 & 1 & 4 \\
\cline { 2 - 8 } & D2Nom18 & 25 & 27 & -2 & 5 & 11 & 12 \\
\cline { 2 - 8 } & D2Nbogus & 44 & 55 & 20 & 21 & -1 & 4 \\
\hline
\end{tabular}



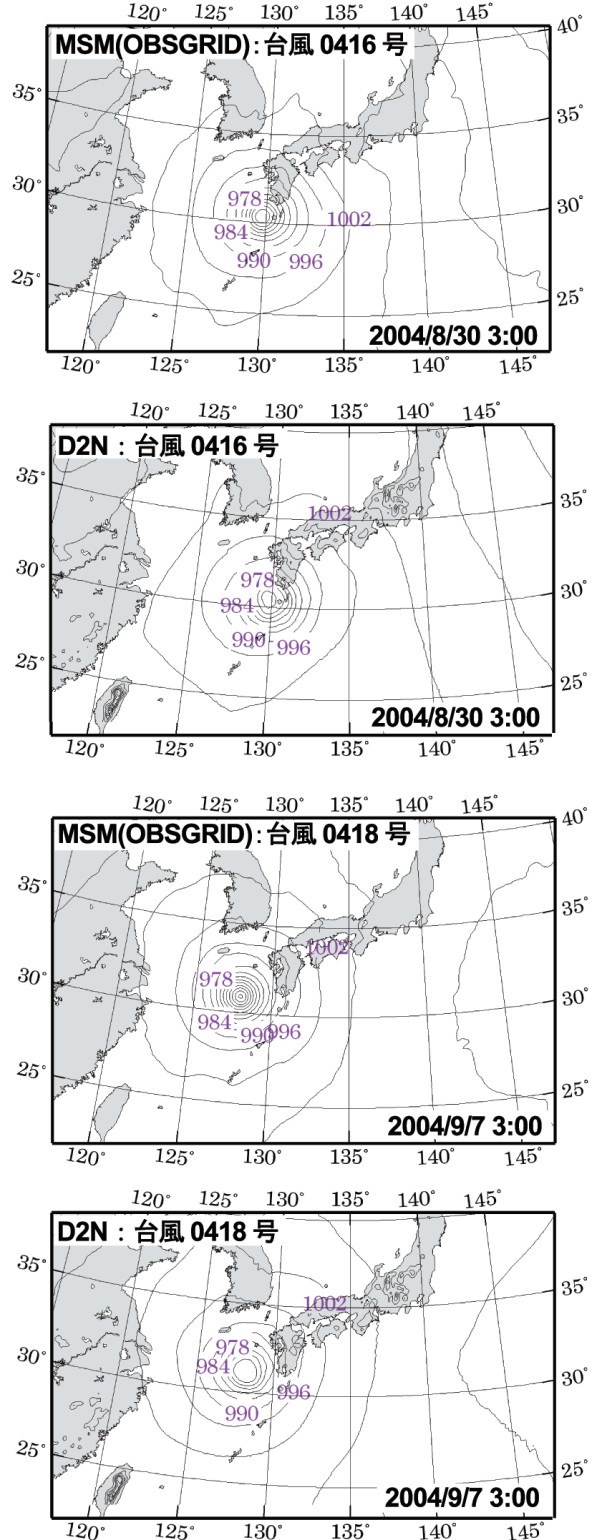

図-6 代表時刻の気圧分布の比較

ー夕に対する感度解析と効果の特定を行うには不十分で あり，今後も同様な検討を行っていく必要がある.

図-6は，台風0416号と0418号に対するケースD2Nの 計算結果と, MSMの代表時刻における気圧分布の比較 結果の一例である。概ね妥当な再現が行われていること が確認できるが，中心気圧の過小評価により，台風中心 位置おいて等圧線の密度が異なる。

図-7では台風0416号を対象に，代表地点において観測 風速と気圧の比較を行った。 ケース毎に若干のばらつき はあるものの, 計算結果は観測結果を概ね良好に再現し ている. 風速及び地上気圧ともに, 台風の中心気圧がべ

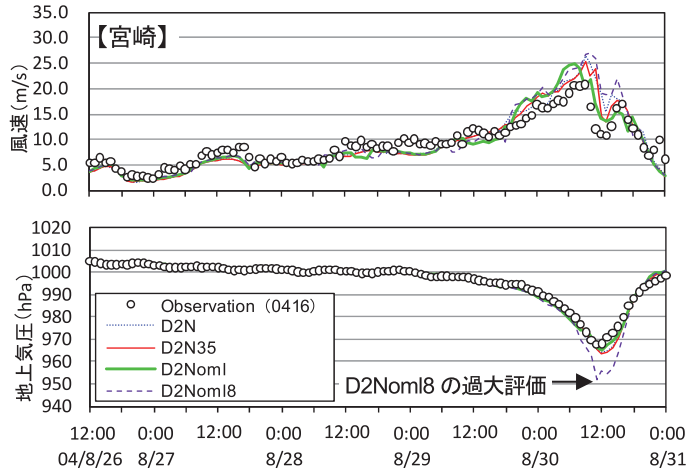

図-7 観測值と計算值の比較

ストトラックを過小評価した D2N～D 2Nomlのケースで 再現性がよく，過大評価傾向にあったD2Nom18ではその まま過大評価となる，台風ボーガスの投入が不十分であ ったD2Nbogusのケースの比較は行わない.

ここで，計算気圧と観測気圧を比較する場合，抽出格 子の標高と観測地点の標高の差の情報から気圧差を計算 し，計算気圧を補正する必要がある。例えば宮崎では， 計算格子の標高が $123.5 \mathrm{~m}$, 観測地点の標高が $9.2 \mathrm{~m}$ であり, 気圧差は概算 $13 \mathrm{hPa}(=(123.5 \mathrm{~m}-9.2 \mathrm{~m}) \times 11.38 \mathrm{pa})$ となる. 地形の近似精度が粗い計算結果を用いて気圧の比較を行 う場合は特に注意を要する。

\section{4. おわりに}

WRFの計算特性として, 台風経路の再現性はNudging による4次元同化の影響が大きく, 中心気圧や風速は物 理モデルのパラメー夕選択の影響が大きいことが明らか となった. ただし本研究では, 多数のパラメー夕の感度 分析や効果の特定までは至らなかった。今後もこのよう な検討を継続していくことが必要と考えられる，その一 方で，実務においても一般的な技術者が，必要な精度の 気象計算を実施可能にする, 気象モデルの利用に関する ガイドラインなどの整備が望まれる.

\section{参 考 文 献}

岡垣 晶 - 大野木和敏 - 高坂裕貴 - 酒它啓司 (2010) : 気象庁 全球解析における台風ボーガスの改良，2010年度秋季大 会講演予稿集, $225 \mathrm{p}$.

中野俊夫 ·山城 賢・橋本典明 · 大西健二 (2010)：4DVAR を用いた台風 9918 号の追算, 土木学会論文集 B2（海岸工 学), Vol. 66, No. 1, pp. 381-385.

安田誠宏 - 山口達也・金 洙列 - 島田広昭 - 石垣泰輔 - 間瀬 肇（2008）：潮汐・高潮・波浪結合モデルとメソ気象モデ ルWRFを用いた瀬戸内海における高潮再現計算に関する 研究, 海岸工学論文集, 第 55巻, pp. 331-335.

安田誠宏・山口達也・金洙列 ·森 信人 ・ 間瀬 肇 (2009) : 気象モデルにおける4次元デー夕同化およびネス ティングが高潮推算精度に及ぼす影響に関する研究, 土 木学会論文集 B2 (海岸工学), Vol. B2-65, pp. 381-385. 